Article

\title{
An Evaluation of Public Spaces with the Use of Direct and Remote Methods
}

\author{
Agnieszka Szczepańska * (D) and Katarzyna Pietrzyk \\ Department of Socio-Economic Geography, Institute of Spatial Management and Geography, \\ Faculty of Geoengineering, University of Warmia and Mazury in Olsztyn, Prawocheńskiego 15, 10-724 Olsztyn, \\ Poland; katarzyna.pietrzyk@uwm.edu.pl \\ * Correspondence: aszczep@uwm.edu.pl
}

Received: 24 September 2020; Accepted: 28 October 2020; Published: 30 October 2020

\begin{abstract}
Public spaces play many important roles and constitute a vital component of the urban fabric, in particular in towns with historical centers. Effective management of public space should be based on the results of qualitative assessments. The quality of public space is usually evaluated directly during field surveys. However, field methods require considerable effort and time, which is why a remote sensing method based on satellite images and the Street View technology was proposed in this paper. Two Polish towns were evaluated, and the results generated by the direct and the remote approach were compared. The assessment focused on public spaces which constitute public property and promote direct human interactions. Both methods produced highly similar results, which indicates that remote sensing is a suitable technique for assessing the quality of public spaces.
\end{abstract}

Keywords: spatial order; public space; quality of public space; remote method

\section{Introduction}

Since the dawn of human civilization, public spaces have played a significant role in cities by delivering numerous benefits to individuals and communities [1-9]. Public spaces are integral elements of the urban fabric which are responsible for the form and structure of cities, and which influence the quality of urban life. Public spaces evolve dynamically and play an increasingly important role in urban development, which is why their quality should be investigated [10-13]. A thorough knowledge of public space quality is required for effective management [14-16], and the existing condition of public spaces constitutes a point of departure for planning new solutions. The above applies particularly to towns and cities with historical centers $[17,18]$ which are protected heritage sites, especially in Eastern Europe where historical city centers are in a state of disrepair due to many years of neglect [19].

Public spaces are highly diverse, which is why their quality is not always easy to assess. Various types and forms of public spaces are encountered in cities, including squares, streets, markets, parks, sidewalks, shopping centers, community centers, playgrounds, schoolyards, and urban interiors. The concept of public space originated in antiquity, and certain types of public space with a similar layout have survived to this day $[6,20,21]$. However, the character of public spaces has evolved considerably due to economic, technological, and social progress. Public spaces serve multiple functions and permeate one another. For this reason, the use of a single approach to the classification (open vs. closed, interior vs. exterior, dominant functions, management, layout, role, location) and evaluation of public spaces could be problematic. Space evolves continuously, and hybrid structures combining several functions, characteristics, forms, and uses are being developed [1,22-25].

The evaluated features and the relevant research methods can differ across various types and forms of public space. Most research into the quality of public spaces focuses on public green spaces, in particular parks [26-32] as well as streets and squares [33-35]. 
The quality of public spaces is generally evaluated based on two criteria: functionality and physical attributes [36]. Various methods for assessing the quality of public spaces have been developed, including remote sensing techniques [31], Google Earth [37], GIS tools [38-40], direct observations (visual analysis) combined with mathematical modeling [41,42], interviews with local community members $[2,29,43,44]$, or a combination of the above methods [45]. Field surveys require considerable effort and time, but they generate highly accurate results and explore the opinions of local community members. Digital techniques are far less time-consuming, but they eliminate the social component from research.

Universal methods for evaluating the quality of public spaces are difficult to design due to considerable variations in the form and functions of public spaces. Despite the fact that public spaces are always specific in terms of type, function, location, environment, and cultural background, their quality should be assessed with the involvement of universal methods. This study proposes a method for evaluating the quality of public spaces in historical centers of small towns based on spatial order components. The proposed methodology involves both qualitative and quantitative assessments, and it can be deployed remotely.

For the needs of this study, public space was defined as physical space that is open to all. The study explored open public spaces in the historical centers of two Polish towns dating back to Medieval times. Public spaces for analysis were selected based on the definition proposed by Stanley et al. [6], p. 1089 who noted that public space is "any urban ground space, regardless of public accessibility, that is not roofed by an architectural structure". In the analyzed cases, public space was defined as space that promotes direct human interactions, has social and integrative functions, is publicly owned, is open to members of the public, and shapes the town's image and identity. Streets and pedestrian zones (pavements) were excluded from the analysis because they do not contribute to social integration in the evaluated towns. Both main and access roads (residential roads) merely distribute vehicular traffic. In small Polish towns, roads do not integrate traffic functions with commercial functions, pavements are not widely used, and human contacts are limited. Therefore, traffic areas are public spaces that are used only temporarily and do not promote social contact. The analysis focused on public spaces that are used for recreational purposes by members of the local community.

The aim of this study was to evaluate the applicability of remote sensing (as compared with direct observations in the field) for assessing the quality of public spaces with the involvement of the same evaluation method. The study was designed to determine whether assessments that do not involve direct observations are possible and reliable on the assumption that field observations generate more accurate results.

The following urban spaces were analyzed in the study: historical municipal parks, market squares, public green spaces, sports fields, playgrounds, urban interiors, and municipal squares. These public spaces were evaluated directly and remotely with the use of the proposed, exemplary methodology. Field surveys and analyses of satellite images conducted with a modified version of the proposed method generated comparable results, which indicates that the quality of public spaces can be assessed reliably by remote sensing. In successive parts of the research project, the results of the described pilot study will be used to develop a universal method for evaluating the quality of public spaces.

\section{Materials and Methods}

\subsection{Research Procedure}

Two Polish cities with historical centers were selected for the study for the purpose of verifying the methodological assumptions and the obtained results. The study was carried out in 2018-2019. A direct survey was conducted in 2018, and a remote sensing analysis was carried out in 2019 . The study covered a period of two years to eliminate the bias resulting from the field survey in the remote sensing analysis. The remote sensing analysis was based on 2018 data. 
The research procedure comprised the following stages:

selection of the study objects-historical centers of two small towns (with a population of up to 20,000 ),

selection of the types of public spaces based on the adopted criteria,

inventory of different types of public spaces in the analyzed towns,

development of maps depicting the distribution of different types of public spaces and their boundaries,

direct evaluation of the quality of public spaces during a field survey with the use of the proposed method,

remote evaluation of the quality of public spaces with the use of a modified version of the proposed method, based on Google Earth resources,

comparison of the results generated by the direct survey and the remote sensing analysis (descriptive and graphic presentation of the results).

\subsection{Study Objects}

The pilot study was conducted in the historical centers of two Polish towns: Morag and Orneta. The towns are situated in the northern part of Poland (Region of Warmia and Mazury) which is known as the Green Lungs of Poland or the Land of a Thousand Lakes (Figure 1). The studied region is characterized by unspoiled nature (high levels of biodiversity, abundance of water bodies, forests, fauna and flora), high tourism potential, as well as numerous historical and cultural heritage sites [46-48].

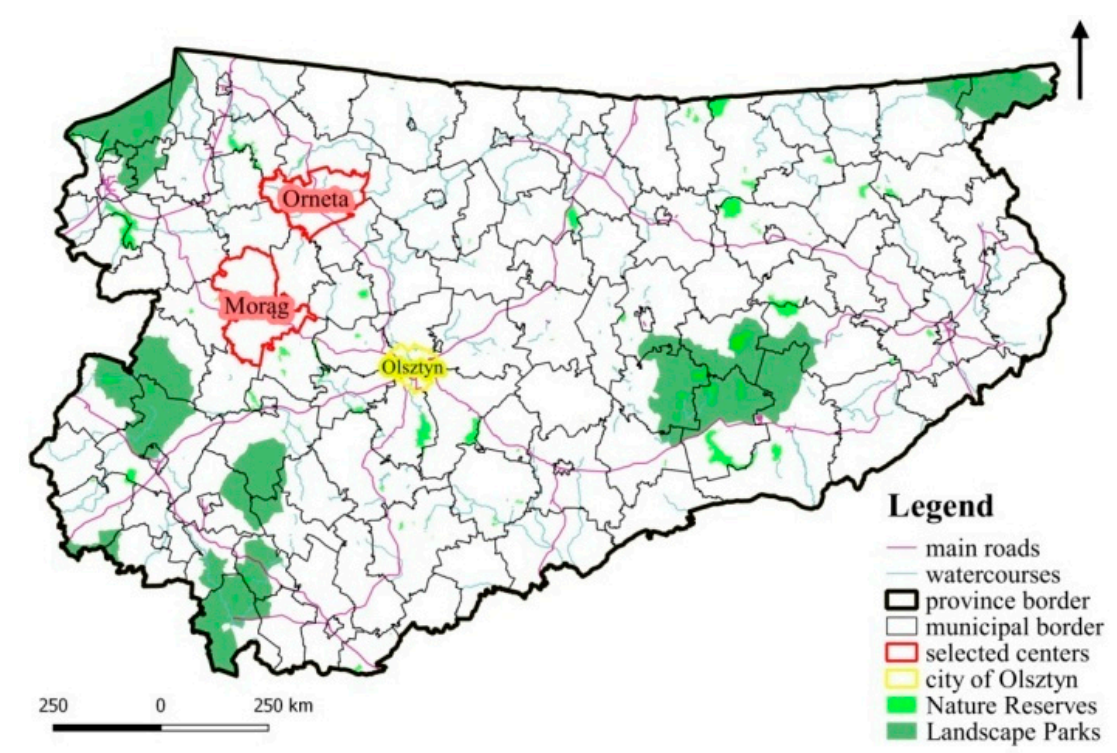

Figure 1. Location of the analyzed towns. Source: own elaboration.

Orneta and Morag are the economic, social, and cultural hubs of their respective municipalities. They feature numerous heritage sites, including remnants of defensive walls. The studied towns are separated by a distance of around $30 \mathrm{~km}$. Morag has an area of $6.11 \mathrm{~km}^{2}$, and it was inhabited by 13,994 people in 2017. Orneta has an area of $9.63 \mathrm{~km}^{2}$ and a population of 8924 (Statistics Poland). The study analyzed the historical centers of Morag and Orneta which feature high-density multifamily residential housing and public services (Figure 2). 

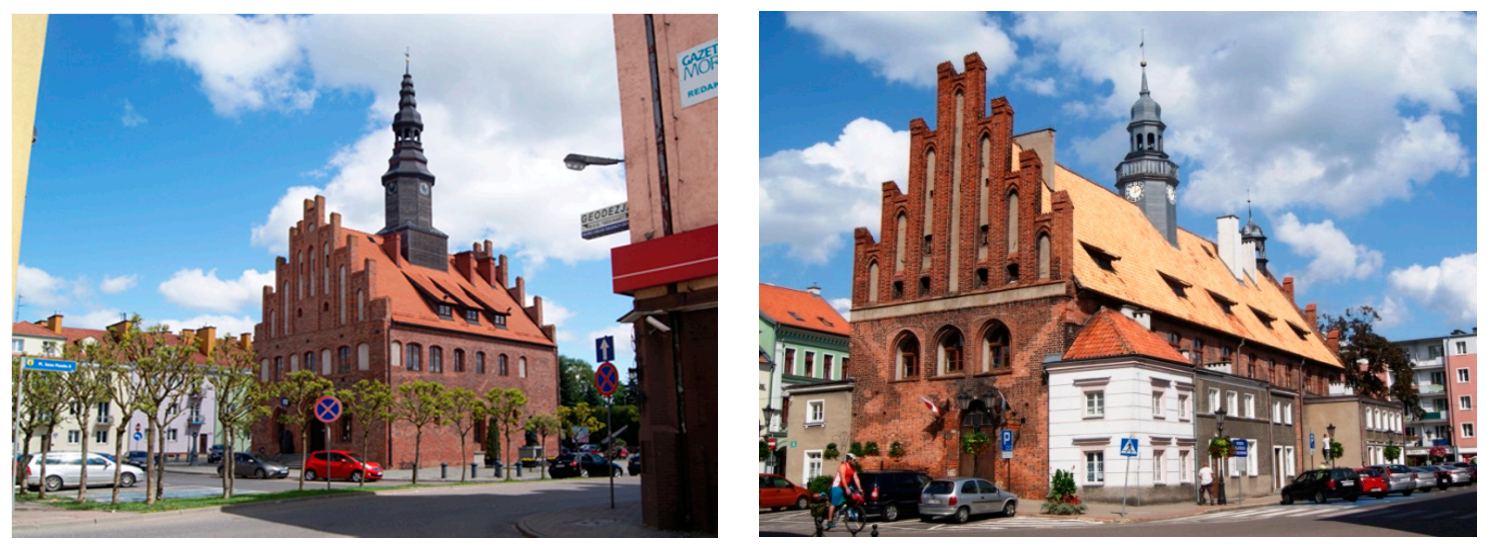

Figure 2. Town halls in Morag and Orneta. Source: own elaboration.

In Morag, the analysis was conducted in the Old Town district. The district is enclosed by remnants of defensive walls that marked the town's boundaries in the 18th century [49]. The Old Town has around 1200 residents. Orneta is not divided into administrative districts, and the studied area was determined based on the location of defensive walls that enclosed the town in the 14th century. The studied area has an estimated population of 1000 people. The local residents differ in income levels, and old-age pensioners constitute the largest demographic group. Both towns struggle with poverty and unemployment, and many members of the local communities rely on welfare.

The evaluated areas have many similarities. Both are covered by local land zoning plans, and their historical buildings and structures are protected heritage and archeological sites. Both districts feature centrally located town halls (Figure 2) surrounded by historical churches, closed urban interiors, rows of tenement buildings, and narrow streets. There are no undeveloped areas or recreational areas. Unorganized green spaces and allotment gardens stretch along the boundaries of both analyzed districts.

\subsection{Selection and Inventory of Public Spaces}

The study investigated public spaces that influence the local community's quality of life. Public spaces were selected for analysis on the following assumptions: members of the local community are the main users of public spaces; public spaces that are used by seniors (the largest demographic group) play an important role in the analyzed towns; public spaces are frequently used by local community members; public spaces stimulate community participation and promote social integration; traffic routes do not constitute public spaces. Areas that did not meet the above assumptions were eliminated, and the following types of public spaces were ultimately included in the analysis: municipal squares, markets, urban interiors, municipal parks, public green spaces, playgrounds, sports fields, unorganized green spaces. The above areas were inventoried in both towns, and their boundaries were marked on maps (Figures 3 and 4).

\subsection{Direct Approach to Evaluating the Quality of Public Spaces}

In the direct approach, the quality of public spaces was evaluated with the use of a self-designed method. The assessment was based on the components of spatial order with qualitative and quantitative attributes. The proposed method accounts for the unique character of historical centers in small towns as well as the attributes of local communities. The method was developed based on a report of the Gdańsk Development Office, entitled "A Study of Municipal Public Spaces-Workshop 2014. An Evaluation of the Attractiveness of Public Spaces" [50]. The original research method was extensively modified as regards public space components and the rated elements. The purpose of the introduced modifications was to eliminate elements that are characteristic of large cities (such as Gdańsk) and are not encountered in small towns (such as intelligent management systems, monitoring systems, and the size of public spaces in the historical centers of small towns which are generally similar). Elements that are repeatable 
and characteristic of historical centers in small towns were incorporated into the modified research methodology (such as architectural and historical monuments, green spaces-proportional design, style). The developed method was modified based on a review of the literature [43,51-55], as well as the analyses conducted by the authors $[44,56]$. The existing methods had to be modified for the needs of the study to account for the unique character of the analyzed public spaces, including differences in quality, historical fabric, and types of use (tourism, municipal management, community needs) relative to medium-sized and large cities.

The developed method supports direct evaluations of the quality of public spaces during field surveys. The quality of space was assessed based on five domains of spatial order: architectural, functional, esthetic, environmental, and social. The components of each domain were itemized in evaluation cards, and each component was evaluated on the adopted grading scale (Table 1).

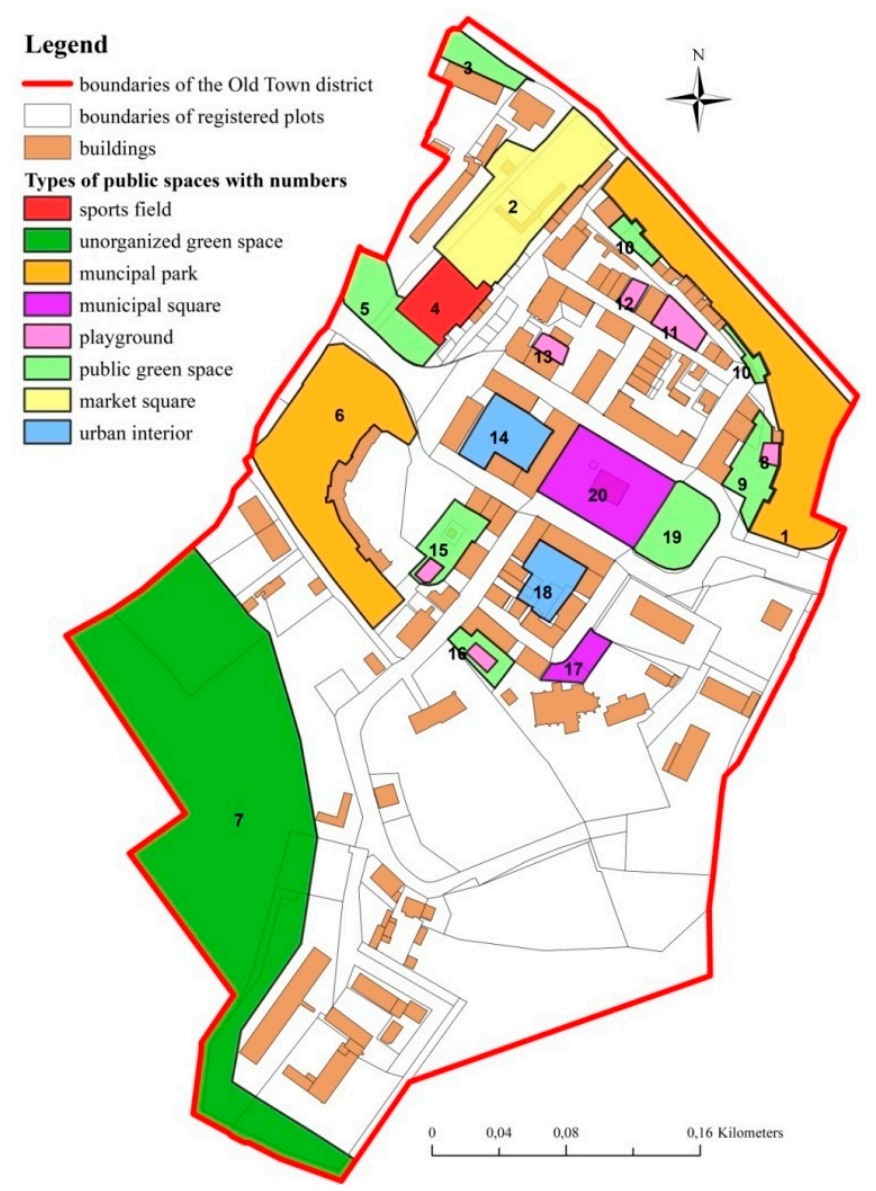

Figure 3. Distribution of public spaces in the center of Morag. Source: own elaboration. Description of public spaces: 1 . Historical municipal park; 2. Market square; 3. Public green space; 4. Sports field; 5. Public green space; 6. Municipal park (behind Dohn Palace); 7. Unorganized green space; 8. Playground; 9. Public green space; 10. Public greens and recreational areas; 11. Playground; 12. Playground; 13. Playground; 14 . Urban interior; 15. Playground with public green space; 16. Playground with public green space; 17. Municipal square. 18. Urban interior; 19. Public green space; 20. Municipal square. 


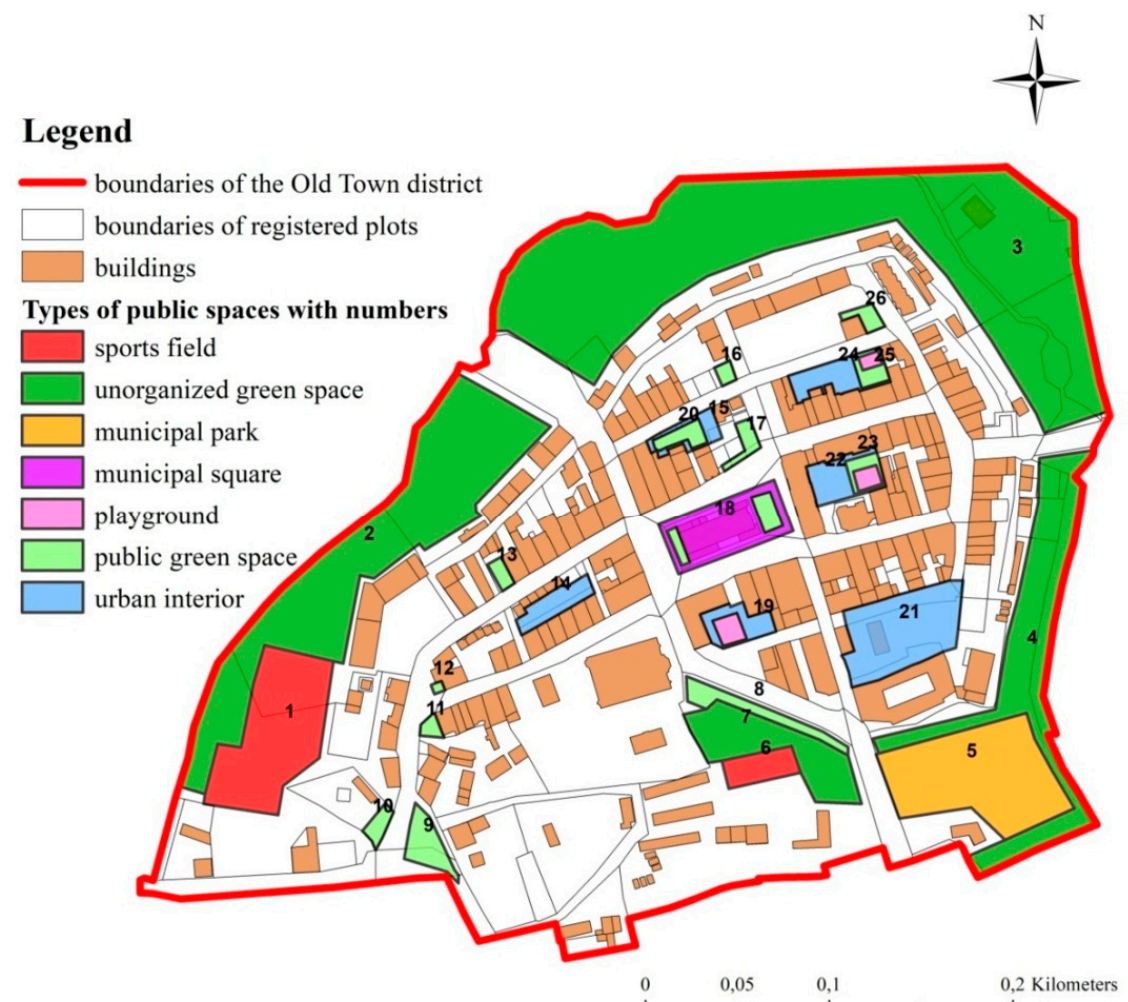

Figure 4. Distribution of public spaces in the center of Orneta. Source: own elaboration. Description of public spaces: 1. Sports field, 2. Unorganized green space, 3. Unorganized green space, 4. Unorganized green space, 5. Municipal park (under construction)/green space, 6. Sports field, 7. Unorganized green space, 8. Public green space, 9. Public green space, 10. Public green space, 11. Public green space, 12. Public green space, 13. Public green space, 14. Urban interior, 15. Urban interior, 16. Public green space, 17. Public green space, 18. Municipal square with public green space, 19. Urban interior with playground, 20. Public green space, 21. Urban interior, 22. Urban interior, 23. Playground with public green space, 24. Urban interior, 25. Playground with public green space, 26. Public green space.

Spatial order components (rated elements in Table 1) were selected based on a review of the literature. The analyzed components were tested in various public spaces in small towns, and the components for the study were selected by elimination. This approach supported the development of a list of components that was highly detailed, yet universally applicable.

The selected components were evaluated on the following grading scale:

- " " " for elements whose quality exceeds basic criteria,

- $\quad$ "0" for elements whose quality meets basic criteria,

- $\quad$ "_ for elements whose quality is below basic criteria.

- "NA"-elements that were not identified in the analyzed public spaces.

The basic criteria, or the basic values (" 0 " value), for every rated element were determined based on a review of the literature as well as architectural and urban planning studies. The basic criterion denotes the optimal and the most desirable quality of the assessed component which supports full, optimal, and problem-free use of public space. 
Table 1. Domains and components of spatial order for evaluating the quality of public spaces. Source: own elaboration based on [50].

\begin{tabular}{|c|c|c|}
\hline Spatial Order & Components & Rated Elements \\
\hline Architectural & $\begin{array}{l}\text { General proportions, urban morphology, urban planning, } \\
\text { craftsmanship and style, additional features, green spaces }\end{array}$ & $\begin{array}{l}\text { 1. adequate surface parameters, } 2 \text {. adequate height parameters, } 3 \text {. adequate } \\
\text { distance between spaces with different functions, } 4 \text {. urban planning solutions, } \\
\text { 5. roofs and canopies, } 6 \text {. sitting areas (quantity), } 7 \text {. sitting areas (quality), } \\
\text { 8. trash cans, 9. garbage containers, 10. lighting (quantity and quality), } \\
\text { 11. playground facilities, } 12 \text {. tables, 13. laundry drying facilities, 14. carpet } \\
\text { beating frames, 15. garages, coal sheds, 16. services, 17. residential buildings, } \\
\text { 18. quality of pedestrian surfaces, 19. recreational areas, 20. safety, 21. style, } \\
\text { 22. architectural and historical monuments, 23. green spaces-cohesion, } \\
\text { 24. green spaces-proportional design, 25. shade producing trees }\end{array}$ \\
\hline Esthetic & $\begin{array}{l}\text { Display of information, advertising and signs, facades, roofs, } \\
\text { pavement and fencing, color scheme, cleanliness }\end{array}$ & $\begin{array}{l}\text { 1. availability and maintenance of public information signs (traffic signs, } \\
\text { information boards on buildings), } 2 \text {. non-organized advertising and organized } \\
\text { advertising, 3. signboards, } 4 \text {. facades-maintenance, } 5 \text {. roofs-maintenance, } \\
\text { 6. paved surfaces-maintenance, } 7 \text {. fences-maintenance, } 8 \text {. pavement } \\
\text { materials, } 9 \text {. fencing materials, } 10 \text {. facade color, } 11 \text {. roof color, } 12 \text {. pavement } \\
\text { color, 13. fence color, } 14 \text {. general cleanliness, } 15 \text {. cleanliness of buildings and } \\
\text { public facilities, } 16 \text {. cleanliness in public green spaces }\end{array}$ \\
\hline Social & $\begin{array}{c}\text { Users, atmosphere, access to other public spaces, safety, } \\
\text { lighting, surveillance }\end{array}$ & $\begin{array}{l}\text { 1. number of users, } 2 \text {. social and demographic structure, } \\
\text { 3. atmosphere-subjective evaluation, } 4 \text {. availability of public spaces within a } \\
100 \text { m radius, 5. ratio of male to female users, } 6 \text {. subjective evaluation of safety, } \\
\text { 7. lighting, } 8 \text {. surveillance }\end{array}$ \\
\hline Environmental & Noise, green spaces & 1. noise levels, 2 . greenery \\
\hline Functional & Footpaths and bike paths, rhythm and harmony, accessibility & $\begin{array}{l}\text { 1. width of sidewalks, } 2 \text {. disabled access, } 3 \text {. bike paths, } 4 \text {. obstacles to pedestrian } \\
\text { traffic, } 5 \text {. unconstrained flow of traffic, traffic safety, } 6 \text {. harmonious space, } 7 \text {. car } \\
\text { parks, } 8 \text {. intensity of vehicular traffic, } 9 \text {. subjective evaluation of the entire space }\end{array}$ \\
\hline
\end{tabular}




\subsection{Remote Approach to Evaluating the Quality of Public Spaces}

The method and components applied in the direct approach were also used in the remote approach to evaluate the quality of public spaces. The remote approach relied on the Google Earth engine. The program supports remote sensing based on satellite images and the Street View technology. The availability of public spaces was the qualifying criterion in the applied tool. Satellite images provide an aerial view, whereas the Street View technology provides a $360^{\circ}$ panorama of the analyzed areas from the user's perspective. This approach creates access to general as well as highly detailed information.

The remote approach was tested on several public spaces. Two sites representing each type of public space were selected for analysis. Some components were difficult to evaluate, and their assessment did not produce reliable results. For example, problems were encountered during remote evaluations of urban lighting. The remote approach supported assessments of the visual quality, but not the practicality of urban lighting. Remote sensing was not effective in determining the illuminated area, the functionality of streetlamps after dark or their ability to illuminate problematic areas. These considerations directly influence the quality of public spaces. Based on the results of the preliminary test, 13 components were eliminated from the study: safety of architectural features, lighting, number of light sources, intensity of vehicular traffic, unconstrained flow of traffic, obstacles to pedestrian traffic, quality of pedestrian surfaces/areas, noise levels, number of users, ratio of male to female users, social and demographic variables, atmosphere, safety-subjective evaluation.

\section{Results}

\subsection{Inventory Results}

The evaluated public spaces were divided into different categories based on the results of the inventory. Several spaces combined two functions, where neither function was predominant. Such areas were assigned to both corresponding categories. Twenty public spaces were inventoried in Morag, and 26 public spaces were identified in Orneta. The results are presented in Table 2.

Table 2. List of public spaces inventoried in Morag and Orneta. Source: own elaboration.

\begin{tabular}{ccc}
\hline Type of Public Space & Number of Public Spaces-Morag & Number of Public Spaces-Orneta \\
\hline Historical municipal park & 1 & - \\
\hline Municipal park/green space & - & 1 \\
\hline Municipal park & 1 & - \\
\hline Sports field & 1 & - \\
\hline Market square & 1 & 10 \\
\hline Public green space & 5 & 4 \\
\hline Unorganized green space & 1 & - \\
\hline Playground & 4 & 2 \\
\hline Playground with public green \\
space
\end{tabular}

The results of the inventory are also presented graphically in Figures 3 and 4 which depict the spatial distribution of public spaces in the studied areas.

The historical center of Morag abounds in playgrounds and public green spaces, whereas the center of Orneta is characterized by a predominance of urban interiors, public green spaces, and unorganized 
green spaces. The inventoried public spaces serve mainly recreational functions. Some spaces were also used for services, pedestrian traffic, sports, and religious worship.

Public spaces are unevenly distributed in the historical center of Morag. They are concentrated mainly in the northern and central parts of the analyzed area, whereas the southern part features mostly unorganized green spaces. These disproportions can be attributed to the presence of castle ruins and green areas in the southern part of the analyzed district. Public spaces are distributed far more evenly in the center of Orneta, and nearly the entire district is surrounded by unorganized green spaces.

The inventory also revealed a high number of historical buildings and structures, diverse spatial management functions, low functionality, low esthetic appeal, and undesirable use of public spaces (some playgrounds were converted to parking lots) in both towns. The historical center of Morag is characterized by considerable esthetic disharmony. The area surrounding the Town Hall is well maintained, but the remaining parts of the Old Town district have not been renovated. Such disproportions were not observed in the center of Orneta where esthetic levels were generally low and similar.

\subsection{The Results of Public Space Evaluation in the Direct and the Remote Approach}

Public spaces were evaluated by the two authors of this article and by two local social activists who participate in campaigns aiming to revitalize historical public spaces in the analyzed towns. The authors and the activists rated all elements and components directly and remotely. The results were presented as the average scores from four independent evaluations. The analysis covered the period of 2018-2019 to eliminate bias resulting from the results of the direct evaluation. No changes occurred in the analyzed public spaces in the evaluated period.

The direct evaluation of the quality of public spaces was completed without any problems. However, two problems were encountered in the remote analysis. The first was the validity of the analyzed data. Google Earth images are updated once a month on average. According to the information displayed on the Google Earth website during the study, the images had been last updated in 2019. However, Google Earth users claim that the images date back 1-3 years on average, and these observations were confirmed during the random verification process described below. Street View images were even older. The images of Orneta and Morag were acquired in May/June 2013, i.e., 5-6 years before the field survey.

For this reason, public space No. 19 in Orneta (urban interior with a playground) was excluded from the analysis. This area is clearly visible in Google Earth and Street View, but the relevant images were acquired in 2013. Public space No. 19 had changed significantly since 2013, and the green square depicted in satellite images has been since converted to a playground. The urban interior and its constituent elements have been renovated or completely modified, including sidewalks, the facade, streetlamps, and the roof.

In turn, the images of Morag were of poor quality. Public space No. 18 could not be analyzed by remote sensing because the corresponding image in Google Earth was blurred, and Street View images were not available.

The results of direct and remote sensing analyses were presented in a descriptive and graphic form. The results generated for every analyzed space were presented relative to the proportion of elements in a given quality class or elements that were not identified in the evaluated areas (in relation to the grading scale). The components of every public space were not described in detail due to space constraints. Only the percentage of components (in the total number of evaluated elements) that were similar or different in the examined areas was presented. The percentage of elements that received a similar score and the percentage of elements that received different scores in the direct and remote approach was indicated. Elements that received identical or completely different scores in the compared approaches were also indicated.

The results of the evaluation of public space quality are presented in Tables 3 and 4 . The percentage of elements characterized by low (below basic criteria), standard (meeting basic 
criteria), and above-standard (exceeding basic criteria) quality and the percentage of unidentified elements was determined in each studied area. The similarities and differences in the results generated by both approaches were color-coded in Tables 3 and 4 for improved readability. The results that differed by up to $10 \%$ were marked in green, the results that differed by 10-20\% were marked in yellow, and the results that differed by more than $20 \%$ were marked in red. The intervals were right-bounded.

The results generated by direct and remote analyses of the Old Town district in Orneta are presented in Table 4. The methodological assumptions and the color-coding scheme are identical to those described in Table 3.

The results of a comparison of direct and remote analyses, shown in Tables 3 and 4, are presented graphically in Figures 5 and 6 based on the average values of four differences between the direct approach and the remote approach. The color-coding scheme is identical to that applied in Tables 3 and 4 . The average values of the observed differences are presented in a separate table in each figure drawing.

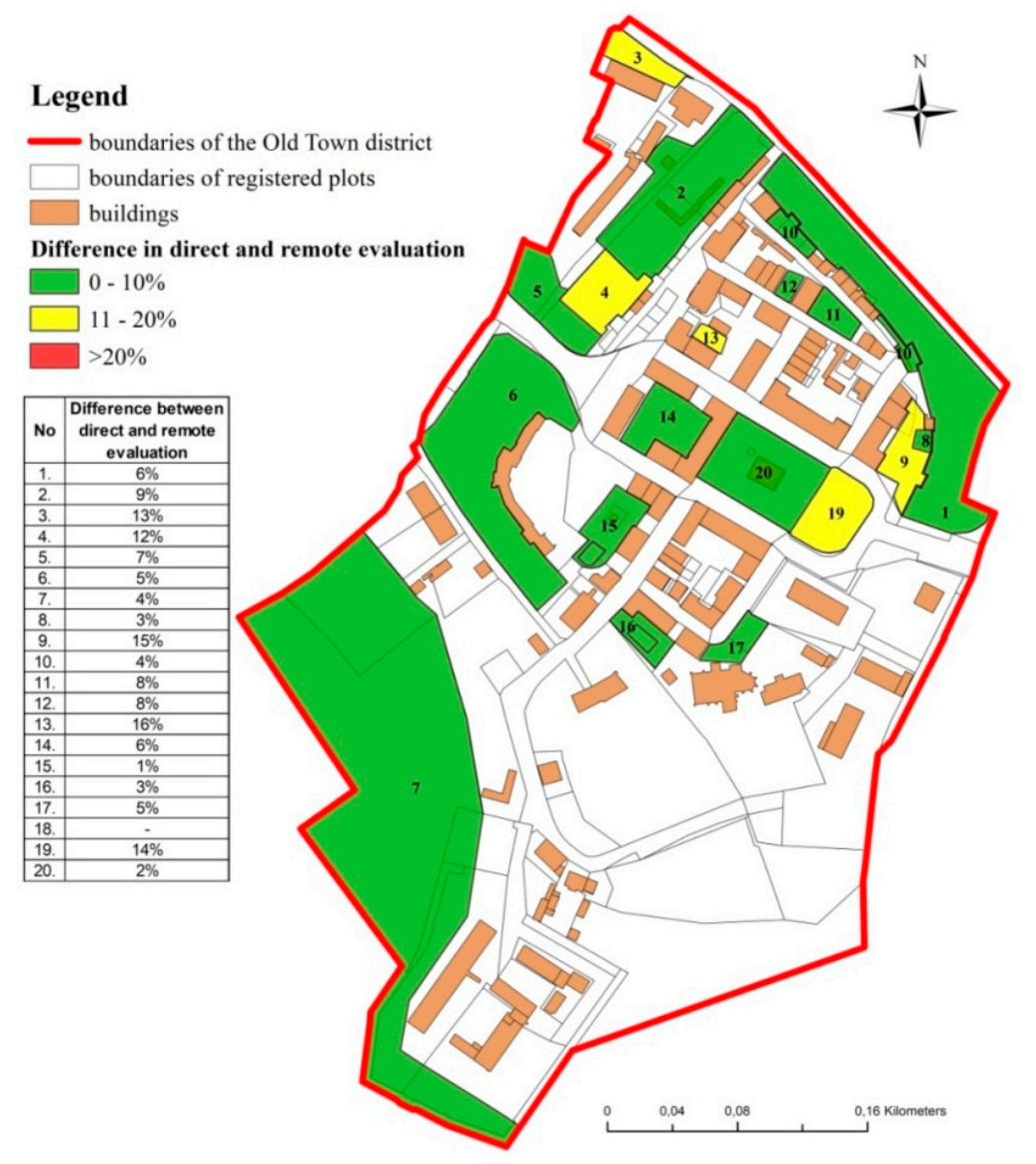

Figure 5. Average differences in the quality of public space elements evaluated in the direct and the remote approach in Morag. Source: own elaboration. 
Table 3. An evaluation of the quality of public spaces—a comparison of the results of direct and remote analyses for Morag. Source: own elaboration.

\begin{tabular}{|c|c|c|c|c|c|c|c|c|c|}
\hline \multirow{3}{*}{ No. } & \multirow{3}{*}{ Public Space } & \multicolumn{8}{|c|}{ Percentage of Components } \\
\hline & & Direct Approach & Remote Approach & Direct Approach & Remote Approach & Direct Approach & Remote Approach & Direct Approach & Remote Approach \\
\hline & & \multicolumn{2}{|c|}{ Quality Exceeds Basic Criteria } & \multicolumn{2}{|c|}{ Quality Meets Basic Criteria } & \multicolumn{2}{|c|}{ Quality below Basic Criteria } & \multicolumn{2}{|c|}{ Not Identified } \\
\hline 1. & Historical municipal park & $32 \%$ & $26 \%$ & $16 \%$ & $19 \%$ & $30 \%$ & $38 \%$ & $22 \%$ & $17 \%$ \\
\hline 2. & Market square & $12 \%$ & $2 \%$ & $18 \%$ & $11 \%$ & $62 \%$ & $72 \%$ & $8 \%$ & $15 \%$ \\
\hline 3. & Public green space & $37 \%$ & $21 \%$ & $32 \%$ & $23 \%$ & $15 \%$ & $32 \%$ & $16 \%$ & $24 \%$ \\
\hline 4. & Sports field & $8 \%$ & $11 \%$ & $17 \%$ & $4 \%$ & $60 \%$ & $49 \%$ & $15 \%$ & $36 \%$ \\
\hline 5. & Public green space & $38 \%$ & $34 \%$ & $30 \%$ & $21 \%$ & $10 \%$ & $13 \%$ & $22 \%$ & $32 \%$ \\
\hline 6. & Municipal park & $18 \%$ & $23 \%$ & $32 \%$ & $36 \%$ & $38 \%$ & $30 \%$ & $12 \%$ & $11 \%$ \\
\hline 7. & Unorganized green space & $5 \%$ & $0 \%$ & $5 \%$ & $9 \%$ & $67 \%$ & $70 \%$ & $23 \%$ & $21 \%$ \\
\hline 8. & Playground & $25 \%$ & $21 \%$ & $28 \%$ & $26 \%$ & $35 \%$ & $38 \%$ & $12 \%$ & $15 \%$ \\
\hline 9. & Public green space & $52 \%$ & $23 \%$ & $20 \%$ & $28 \%$ & $16 \%$ & $36 \%$ & $12 \%$ & $13 \%$ \\
\hline 10. & Public green space & $10 \%$ & $4 \%$ & $3 \%$ & $4 \%$ & $83 \%$ & $81 \%$ & $4 \%$ & $11 \%$ \\
\hline 11. & Playground & $12 \%$ & $4 \%$ & $5 \%$ & $11 \%$ & $60 \%$ & $70 \%$ & $23 \%$ & $15 \%$ \\
\hline 12. & Playground & $10 \%$ & $4 \%$ & $12 \%$ & $2 \%$ & $65 \%$ & $81 \%$ & $13 \%$ & $13 \%$ \\
\hline 13. & Playground & $15 \%$ & $2 \%$ & $23 \%$ & $4 \%$ & $50 \%$ & $79 \%$ & $12 \%$ & $15 \%$ \\
\hline 14. & Urban interior & $35 \%$ & $28 \%$ & $22 \%$ & $28 \%$ & $40 \%$ & $36 \%$ & $3 \%$ & $8 \%$ \\
\hline 15. & $\begin{array}{l}\text { Playground with public } \\
\text { green space }\end{array}$ & $27 \%$ & $28 \%$ & $22 \%$ & $23 \%$ & $38 \%$ & $38 \%$ & $13 \%$ & $11 \%$ \\
\hline 16. & $\begin{array}{l}\text { Playground with public } \\
\text { green space }\end{array}$ & $17 \%$ & $13 \%$ & $25 \%$ & $23 \%$ & $52 \%$ & $53 \%$ & $6 \%$ & $11 \%$ \\
\hline 17. & Municipal square & $75 \%$ & $68 \%$ & $2 \%$ & $6 \%$ & $12 \%$ & $9 \%$ & $11 \%$ & $17 \%$ \\
\hline 18. & Urban interior & $28 \%$ & - & $23 \%$ & - & $45 \%$ & - & $4 \%$ & - \\
\hline 19. & Public green space & $63 \%$ & $38 \%$ & $3 \%$ & $19 \%$ & $13 \%$ & $11 \%$ & $21 \%$ & $32 \%$ \\
\hline 20. & Municipal square & $58 \%$ & $62 \%$ & $15 \%$ & $15 \%$ & $15 \%$ & $15 \%$ & $12 \%$ & $8 \%$ \\
\hline
\end{tabular}


Table 4. An evaluation of the quality of public spaces-a comparison of the results of direct and remote analyses for Orneta. Source: own elaboration.

\begin{tabular}{|c|c|c|c|c|c|c|c|c|c|}
\hline \multirow{3}{*}{ No } & \multirow{3}{*}{ Public Space } & \multicolumn{8}{|c|}{ Percentage of Components } \\
\hline & & Direct Approach & Remote Approach & Direct Approach & Remote Approach & Direct Approach & Remote Approach & Direct Approach & Remote Approach \\
\hline & & \multicolumn{2}{|c|}{ Quality Exceeds Basic Criteria } & \multicolumn{2}{|c|}{ Quality Meets Basic Criteria } & \multicolumn{2}{|c|}{ Quality below Basic Criteria } & \multicolumn{2}{|c|}{ Not Identified } \\
\hline 1. & Sports field & $10 \%$ & $19 \%$ & $3 \%$ & $11 \%$ & $53 \%$ & $26 \%$ & $34 \%$ & $44 \%$ \\
\hline 2. & Unorganized green space & $8 \%$ & $17 \%$ & $15 \%$ & $17 \%$ & $53 \%$ & $43 \%$ & $24 \%$ & $23 \%$ \\
\hline 3. & Unorganized green space & $7 \%$ & $15 \%$ & $12 \%$ & $4 \%$ & $57 \%$ & $55 \%$ & $24 \%$ & $26 \%$ \\
\hline 4. & Unorganized green space & $7 \%$ & $13 \%$ & $15 \%$ & $11 \%$ & $60 \%$ & $64 \%$ & $18 \%$ & $12 \%$ \\
\hline 5. & $\begin{array}{l}\text { Municipal park (under } \\
\text { construction)/green space }\end{array}$ & $10 \%$ & $11 \%$ & $7 \%$ & $6 \%$ & $58 \%$ & $64 \%$ & $25 \%$ & $19 \%$ \\
\hline 6. & Sports field & $3 \%$ & $13 \%$ & $3 \%$ & $6 \%$ & $64 \%$ & $45 \%$ & $30 \%$ & $36 \%$ \\
\hline 7. & Unorganized green space & $8 \%$ & $11 \%$ & $10 \%$ & $6 \%$ & $52 \%$ & $45 \%$ & $30 \%$ & $38 \%$ \\
\hline 8. & Public green space & $43 \%$ & $49 \%$ & $13 \%$ & $15 \%$ & $16 \%$ & $9 \%$ & $28 \%$ & $27 \%$ \\
\hline 9. & Public green space & $32 \%$ & $45 \%$ & $32 \%$ & $21 \%$ & $16 \%$ & $9 \%$ & $20 \%$ & $25 \%$ \\
\hline 10. & Public green space & $27 \%$ & $26 \%$ & $30 \%$ & $19 \%$ & $30 \%$ & $38 \%$ & $13 \%$ & $17 \%$ \\
\hline 11. & Public green space & $20 \%$ & $34 \%$ & $17 \%$ & $13 \%$ & $50 \%$ & $32 \%$ & $13 \%$ & $21 \%$ \\
\hline 12. & Public green space & $20 \%$ & $4 \%$ & $23 \%$ & $11 \%$ & $43 \%$ & $68 \%$ & $14 \%$ & $17 \%$ \\
\hline 13. & Public green space & $30 \%$ & $47 \%$ & $18 \%$ & $6 \%$ & $38 \%$ & $26 \%$ & $14 \%$ & $21 \%$ \\
\hline 14. & Urban interior & $10 \%$ & $2 \%$ & $10 \%$ & $6 \%$ & $73 \%$ & $86 \%$ & $7 \%$ & $6 \%$ \\
\hline 15. & Urban interior & $10 \%$ & $28 \%$ & $33 \%$ & $32 \%$ & $55 \%$ & $38 \%$ & $2 \%$ & $2 \%$ \\
\hline 16. & Public green space & $30 \%$ & $6 \%$ & $25 \%$ & $11 \%$ & $37 \%$ & $68 \%$ & $8 \%$ & $15 \%$ \\
\hline 17. & Public green space & $20 \%$ & $15 \%$ & $18 \%$ & $11 \%$ & $48 \%$ & $55 \%$ & $14 \%$ & $19 \%$ \\
\hline 18. & $\begin{array}{l}\text { Municipal square with } \\
\text { public green space }\end{array}$ & $32 \%$ & $36 \%$ & $17 \%$ & $17 \%$ & $38 \%$ & $30 \%$ & $13 \%$ & $17 \%$ \\
\hline 19. & $\begin{array}{l}\text { Urban interior with } \\
\text { playground }\end{array}$ & $58 \%$ & - & $15 \%$ & - & $22 \%$ & - & $5 \%$ & - \\
\hline 20. & Public green space & $25 \%$ & $36 \%$ & $22 \%$ & $19 \%$ & $42 \%$ & $32 \%$ & $11 \%$ & $13 \%$ \\
\hline 21. & Urban interior & $12 \%$ & $13 \%$ & $12 \%$ & $19 \%$ & $74 \%$ & $66 \%$ & $2 \%$ & $2 \%$ \\
\hline 22. & Urban interior & $23 \%$ & $55 \%$ & $33 \%$ & $26 \%$ & $38 \%$ & $11 \%$ & $6 \%$ & $8 \%$ \\
\hline 23. & $\begin{array}{l}\text { Playground with public } \\
\text { green space }\end{array}$ & $15 \%$ & $49 \%$ & $32 \%$ & $13 \%$ & $31 \%$ & $8 \%$ & $22 \%$ & $30 \%$ \\
\hline
\end{tabular}


Table 4. Cont.

\begin{tabular}{|c|c|c|c|c|c|c|c|c|c|}
\hline \multirow{3}{*}{ No } & \multirow{3}{*}{ Public Space } & \multicolumn{8}{|c|}{ Percentage of Components } \\
\hline & & Direct Approach & Remote Approach & Direct Approach & Remote Approach & Direct Approach & Remote Approach & Direct Approach & Remote Approach \\
\hline & & \multicolumn{2}{|c|}{ Quality Exceeds Basic Criteria } & \multicolumn{2}{|c|}{ Quality Meets Basic Criteria } & \multicolumn{2}{|c|}{ Quality below Basic Criteria } & \multicolumn{2}{|c|}{ Not Identified } \\
\hline 24. & Urban interior & $18 \%$ & $57 \%$ & $48 \%$ & $15 \%$ & $32 \%$ & $26 \%$ & $2 \%$ & $2 \%$ \\
\hline 25. & $\begin{array}{l}\text { Playground with public } \\
\text { green space }\end{array}$ & $27 \%$ & $53 \%$ & $33 \%$ & $13 \%$ & $30 \%$ & $21 \%$ & $10 \%$ & $13 \%$ \\
\hline 26. & Public green space & $17 \%$ & $21 \%$ & $18 \%$ & $6 \%$ & $52 \%$ & $49 \%$ & $13 \%$ & $24 \%$ \\
\hline
\end{tabular}




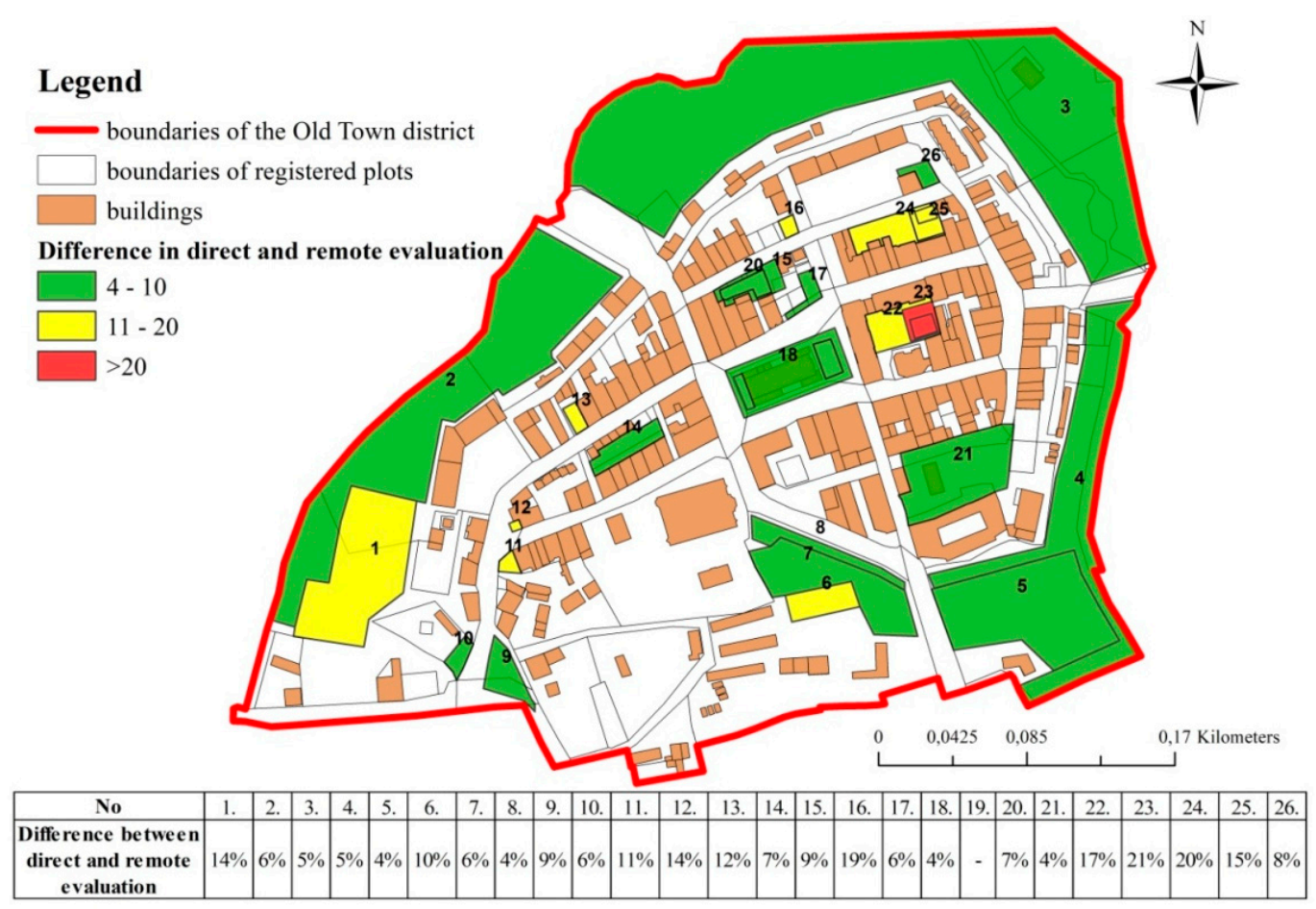

Figure 6. Average differences in the quality of public space elements evaluated in the direct and the remote approach in Orneta. Source: own elaboration.

\section{Discussion}

The analyzed elements did not differ significantly in the majority of the evaluated public spaces, and the differences between the results of direct and remote analyses did not exceed $10 \%$ in most cases (green fields in Tables 3 and 4). However, individual variations were observed (yellow and red fields).

In Morag (Table 3), the greatest differences between components whose quality exceeded basic criteria reached $29 \%$ and $25 \%$. These differences were noted in public green areas. The results of the direct and the remote approach also differed in public areas No. 3 (by 16\%) and 13 (by 13\%). The column denoting elements that meet basic evaluation criteria is nearly entirely marked in green, which indicates that the compared approaches produced similar results. Certain variations were noted in public spaces No. $4(13 \%), 13(19 \%)$, and $19(16 \%)$. The greatest differences were observed in the percentage of components below the basic quality criteria. The relevant discrepancies reached $29 \%$ in public space No. 13 (playground) and 11-20\% in public spaces No. 3, 4, 9, and 12. The last column depicts the percentage of elements that were not identified in the studied areas and were not analyzed. The values noted in both approaches were similar. The greatest difference $(21 \%)$ was noted in the sports field. The results of direct and remote analyses differed most considerably in three types of public spaces: green areas, playgrounds, and the sports field.

In Orneta (Table 4), the greatest difference in components whose quality exceeded basic criteria was observed in public space No. 24 (39\%). The above indicates that 39\% of the elements received higher scores (above the basic quality criteria) in the remote approach than in the direct approach. Differences in excess of $20 \%$ were also noted in public spaces No. 23, 22, and 25 . Differences in the range of $10-20 \%$ (yellow fields) were observed in public spaces No. $9(13 \%), 19(14 \%), 12(16 \%), 13(17 \%)$, $15(18 \%)$, and $20(11 \%)$. The scores assigned to elements that exceeded basic criteria differed by $13 \%$ on average in the compared approaches. The greatest difference between components meeting basic criteria reached $33 \%$ in the urban interior No. 24. Variations were also noted in public spaces 9, 10, $12,13,16,23,25$, and $26(11-20 \%)$. Green spaces were the predominant type of public space in this category. The results of the compared analytical approaches differed by more than $10 \%$ with regard 
to the elements that did not meet basic criteria. Considerable differences were observed in public green spaces. The compared methods produced highly similar results in the category of unidentified elements. The only exception was public space No. 26 (yellow field) where the observed difference reached $11 \%$. In Orneta, the greatest variations were noted in four types of public space: green spaces, playgrounds with green spaces, sports fields, and urban interiors.

In the center of Orneta, the compared analytical approaches produced greater differences than in Morag (Tables 3 and 4). In Morag, differences higher than 10\% were noted in 5 out of the 19 analyzed public spaces (none of them exceeded 20\%), whereas in Orneta, such differences were noted in 16 out of the 26 examined public spaces (only one difference exceeded $20 \%$ ).

The majority of the evaluated public spaces are marked in green in Figure 5, which indicates that they received highly similar scores in both approaches. Most of the noted variations did not exceed $10 \%$, and differences greater than $20 \%$ were observed only in public spaces No. 3, 4, 9, 13 , and 19 . In the Old Town district of Morag, the average difference between the results of the direct approach and the remote approach was only 7\%. In Figure 6, more than half (64\%) of public spaces in Orneta are marked in green, and one-third of the examined areas (32\%) are marked in yellow. Only public space No. 23 is marked in red. The average difference between the results of the direct approach and the remote approach reached 9.7\%, and it was much higher than in Morag. The degree of similarity between public space components evaluated in both towns would probably be much higher if Google Earth and Street View images were updated more frequently.

The above results denote general differences and similarities in the compared analytical approaches. The percentage of public space components (Table 1) which received similar of different scores in the direct and the remote approach is presented in Tables 5 and 6.

There were no public spaces in Morag and Orneta where all of the evaluated components received identical scores in the direct and the remote approach. In Morag, the highest percentage of components that received identical scores in both approaches (65\%) was found in public space No. 10 (green area) (Table 5). The highest percentage of components that received different scores (69\%) was noted in public space No. 3 (green space). Similar observations were made in the center of Orneta, where none of the evaluated public space components received identical scores (Table 6). The highest percentage of elements that received identical scores in both approaches (72\%) was noted in public space No. 14 (urban interior), whereas the greatest discrepancies (62\%) were found in public space No. 22 (urban interior).

Selected public space components received highly similar as well as completely different scores in the direct and the remote approach. None of the examined components were characterized by $100 \%$ similarity in Morag. The elements that differed most significantly (in 17 public spaces) included trash cans (architectural component of spatial order) and cleanliness in public green spaces (esthetic component of spatial order). The availability and maintenance of public information signs (esthetic component of spatial order) received completely different scores in the compared approaches. In Orneta, similar results were generated for bike paths in all investigated areas. The compared approaches produced the most diverse results for public green spaces (environmental component of spatial order) and sitting areas—quality (architectural component of spatial order). The obtained scores differed in 17 public spaces. 
Table 5. The quality of public spaces in Morag-similarities and differences in the results generated by the direct and the remote approach. Source: own elaboration.

\begin{tabular}{|c|c|c|c|}
\hline No. & Public Space & $\begin{array}{l}\text { Percentage of Elements with } \\
\text { Identical Scores in the Direct } \\
\text { and the Remote Approach }\end{array}$ & $\begin{array}{l}\text { Percentage of Elements with } \\
\text { Different Scores in the Direct } \\
\text { and the Remote Approach }\end{array}$ \\
\hline 1. & Historical municipal park & $40 \%$ & $60 \%$ \\
\hline 2. & Market square & $53 \%$ & $47 \%$ \\
\hline 3. & Public green space & $48 \%$ & $52 \%$ \\
\hline 4. & Sports field & $40 \%$ & $60 \%$ \\
\hline 5. & Public green space & $52 \%$ & $48 \%$ \\
\hline 6. & Municipal park & $47 \%$ & $53 \%$ \\
\hline 7. & Unorganized green space & $56 \%$ & $44 \%$ \\
\hline 8. & Playground & $47 \%$ & $53 \%$ \\
\hline 9. & Public green space & $35 \%$ & $65 \%$ \\
\hline 10. & Public green space & $65 \%$ & $35 \%$ \\
\hline 11. & Playground & $50 \%$ & $50 \%$ \\
\hline 12. & Playground & $60 \%$ & $40 \%$ \\
\hline 13. & Playground & $44 \%$ & $56 \%$ \\
\hline 14. & Urban interior & $52 \%$ & $48 \%$ \\
\hline 15. & Playground with public green space & $47 \%$ & $53 \%$ \\
\hline 16. & Playground with public green space & $48 \%$ & $52 \%$ \\
\hline 17. & Municipal square & $63 \%$ & $37 \%$ \\
\hline 18. & Urban interior & - & - \\
\hline 19. & Public green space & $53 \%$ & $47 \%$ \\
\hline \multirow[t]{3}{*}{20.} & Municipal square & $58 \%$ & $42 \%$ \\
\hline & Mean & $50 \%$ & $50 \%$ \\
\hline & Standard deviation & $8 \%$ & $8 \%$ \\
\hline
\end{tabular}

Table 6. The quality of public spaces in Orneta-similarities and differences in the results generated by the direct and the remote approach. Source: own elaboration.

\begin{tabular}{cccc}
\hline No. & Public Space & $\begin{array}{c}\text { Percentage of Elements with } \\
\text { Identical Scores in the Direct } \\
\text { and the Remote Approach }\end{array}$ & $\begin{array}{c}\text { Percentage of Elements with } \\
\text { Different Scores in the Direct } \\
\text { and the Remote Approach }\end{array}$ \\
\hline 1. & Sports field & $63 \%$ & $37 \%$ \\
\hline 2. & Unorganized green space & $63 \%$ & $37 \%$ \\
\hline 3. & Unorganized green space & $62 \%$ & $38 \%$ \\
\hline 4. & Unorganized green space & $53 \%$ & $47 \%$ \\
\hline 5. & Municipal park (under & $58 \%$ & $42 \%$ \\
\hline 6. & construction)/green space & $67 \%$ & $33 \%$ \\
\hline 7. & Sports field & $62 \%$ & $38 \%$ \\
\hline 8. & Unorganized green space & $60 \%$ & $40 \%$ \\
\hline 9. & Public green space & $63 \%$ & $37 \%$ \\
\hline 10. & Public green space & $57 \%$ & $43 \%$ \\
\hline 11. & Public green space & $52 \%$ & $48 \%$ \\
\hline 12. & Public green space & $55 \%$ & $45 \%$ \\
\hline 13. & Public green space & $57 \%$ & $43 \%$ \\
\hline
\end{tabular}


Table 6. Cont

\begin{tabular}{cccc}
\hline No. & Public Space & $\begin{array}{c}\text { Percentage of Elements with } \\
\text { Identical Scores in the Direct } \\
\text { and the Remote Approach }\end{array}$ & $\begin{array}{c}\text { Percentage of Elements with } \\
\text { Different Scores in the Direct } \\
\text { and the Remote Approach }\end{array}$ \\
\hline 14. & Urban interior & $72 \%$ & $28 \%$ \\
\hline 15. & Urban interior & $48 \%$ & $52 \%$ \\
\hline 16. & Public green space & $48 \%$ & $52 \%$ \\
\hline 17. & Public green space & $67 \%$ & $33 \%$ \\
\hline 18. & Municipal square with public green space & $67 \%$ & $33 \%$ \\
\hline 19. & Urban interior with playground & - & - \\
\hline 20. & Public green space & $55 \%$ & $45 \%$ \\
\hline 21. & Urban interior & $67 \%$ & $33 \%$ \\
\hline 22. & Urban interior & $38 \%$ & $62 \%$ \\
\hline 23. & Playground with public green space & $43 \%$ & $57 \%$ \\
\hline 24. & Urban interior & $43 \%$ & $57 \%$ \\
\hline 25. & Playground with public green space & $50 \%$ & $50 \%$ \\
\hline 26. & Public green space & $55 \%$ & $45 \%$ \\
\hline & Mean & $\mathbf{5 7 \%}$ & $\mathbf{4 3} \%$ \\
\hline
\end{tabular}

\section{Summary and Conclusions}

Evaluations of the quality of public space pose a considerable challenge for researchers. Public spaces continue to evolve, which leads to changes in their function, character, and components. Escalating privatization, the declining importance of public spaces, and the progressive loss of local identity suggest that public space could constitute one of the most interesting topics in this research field in the 21st century. Similar conclusions have been formulated in the reports of the world's leading organization. In 2015, the United Nations General Assembly adopted a resolution entitled "Transforming our World: the 2030 Agenda for Sustainable Development" [57] which lays out 17 sustainable development goals. Goal 11, "to make cities and human settlements inclusive, self, resilient and sustainable", is of greatest significance for this study. Goal 11.7, "by 2030, to provide universal access to safe, inclusive and accessible, green and public spaces, in particular for women and children, older persons and persons with disabilities", makes a direct reference to public spaces. The study also indirectly addresses goals 11.3 and 11.4 which promote participatory planning and the protection of cultural and natural heritage. The second major document is the New Urban Agenda adopted by the UN General Assembly in 2016 [58]. The New Urban Agenda for the EU approved under the Pact of Amsterdam applies strictly to Europe where the study was conducted [59]. This document calls on the Member States to implement the EU policies and undertake joint action with the aim of stimulating urban growth and formulating guidelines for sustainable urban development in the future. The document focuses on the major aspects of sustainable urban development, including social, economic, architectural, and environmental. This study makes a direct reference to points 13, 9, 7 and, in particular, 37 of the New Urban Agenda which recognizes that public places "are multifunctional areas for social interaction and inclusion, human health and well-being, economic exchange and cultural expression and dialogue among a wide diversity of people and cultures". These provisions underscore the importance of research into public spaces.

Most analyses of public spaces are conducted in large and medium-sized cities, which is a certain limitation in studies of small towns because the developed research methodologies are generally tailored to the specific characteristics of public spaces in large urban areas. The proposed methodology relied on the existing solutions, but it was modified to account for the unique attributes of small towns with historical centers. As a result, the developed methodology filled in the existing gap. 
The direct approach and the remote approach have several similarities as well as differences. The direct analysis supports the generation of detailed evaluation cards based on visual observations, including observations of the social fabric. This type of information cannot be acquired by remote sensing where digital data are the only reference source. The effectiveness of the remote sensing technique is largely determined by the validity of satellite and Street View images which, in extreme cases, can be several years old. Despite the above, remote sensing significantly shortens analysis time. In comparison with the direct approach, the analysis of one public space took $25-30 \%$ less time. Field surveys require several trips to the examined locations; therefore, the overall time of analysis in the remote approach was more than $10 \mathrm{~h}$ shorter than in the direct approach.

As discussed previously, not all public spaces can be analyzed remotely because some Google Earth images are blurred, and not all public spaces are visualized in the Street View technology.

Despite the indicated weaknesses of remote sensing as well as the fact that none of the evaluated public spaces received identical scores in the compared approaches, the remote sensing technique is a useful tool for preliminary evaluations of the quality of public spaces. The differences in the results generated by the direct and the remote approach (Figures 5 and 6) did not exceed $10 \%$ in most public spaces. These results indicate that the quality of public spaces can be evaluated reliably with the use of both techniques. The percentage of public space components in Morag and Orneta which received similar scores in the compared approaches also indicates that the quality of public spaces can be effectively estimated by remote sensing. Thus, the present study confirmed the applicability of remote sensing in evaluations of public space quality.

The types of public spaces which received the most diverse scores in the compared analytical methods were public green spaces, playgrounds, and a sports field in Morag, and public green spaces, playgrounds with green spaces, sports fields, and urban interiors in Orneta. These types of public spaces evolve most rapidly or are most frequently modified. The reliability of evaluations conducted in these categories of public space is largely determined by the validity of the analyzed data.

Remote sensing analyses of public spaces (with the use of the proposed method or other methods) are most suited for general evaluations that do not require a high level of detail and accuracy. This technique can also be used to compare changes in space over time in the absence of historical data from direct surveys.

The presented evaluation was a pilot study whose results will be used in a larger research project in variously sized urban areas. In the future, streets will also be evaluated as an important element of public spaces in the urban structure. University students pursuing degrees in urban planning and land management as well as members of the local community, including local administration officers responsible for urban planning and architecture, will participate in future research.

The outbreak of the COVID-19 pandemic in 2020 demonstrated that remote sensing is a valuable technique that contributes to the continuity of research in circumstances where direct observations cannot be performed.

Author Contributions: Conceptualization, A.S. and K.P.; methodology, A.S. and K.P.; formal analysis, K.P.; investigation, A.S., resources, K.P.; data curation, K.P.; writing—original draft preparation, A.S. and K.P.; writing-review and editing, A.S.; visualization, K.P.; supervision, A.S.; project administration, A.S. All authors have read and agreed to the published version of the manuscript.

Funding: This research received no external funding.

Conflicts of Interest: The authors declare no conflict of interest. The funders had no role in the design of the study; in the collection, analyses, or interpretation of data; in the writing of the manuscript, or in the decision to publish the results. 


\section{References}

1. Banerjee, T. The future of public space. Beyond invented streets and reinvented places. J. Am. Plan. Assoc. 2001, 67, 9-24. [CrossRef]

2. Pasaogullari, N.; Doratli, N. Measuring accessibility and utilization of public spaces in Famagusta. Cities 2004, 21, 225-232. [CrossRef]

3. Gehl, J. Life between Buildings: Using Public Space; Island Press: Washington, DC, USA, 2011.

4. Francis, J.; Giles-Corti, B.; Wood, L.; Knuiman, M. Creating sense of community: The role of public space. J. Environ. Psychol. 2012, 32, 401-409. [CrossRef]

5. Francis, J.; Wood, L.J.; Knuiman, M.; Giles-Corti, B. Quality or quantity? Exploring the relationship between Public Open Space attributes and mental health in Perth, Western Australia. Soc. Sci. Med. 2012, 74, 1570-1577. [CrossRef] [PubMed]

6. Stanley, B.W.; Stark, B.L.; Johnston, K.L.; Smith, M.E. Urban open spaces in historical perspective: A transdisciplinary typology and analysis. Urban Geogr. 2012, 33, 1089-1117. [CrossRef]

7. Koohsari, M.J.; Mavoa, S.; Villanueva, K.; Sugiyama, T.; Badland, H.; Kaczynski, A.T.; Giles-Corti, B. Public open space, physical activity, urban design and public health: Concepts, methods and research agenda. Health Place 2015, 33, 75-82. [CrossRef] [PubMed]

8. Hadavi, S.; Kaplan, R. Neighborhood satisfaction and use patterns in urban public outdoor spaces: Multidimensionality and two-way relationships. Urban For. Urban Green. 2016, 16, 110-122.

9. Koohsari, M.J.; Badland, H.; Mavoa, S.; Villanueva, K.; Francis, J.; Hooper, P.; Owen, N.; Giles-Corti, B. Are public open space attributes associated with walking and depression? Cities 2018, 74, 119-125. [CrossRef]

10. Altman, I.; Zube, H. Public places and spaces; Springer: New York, NY, USA; Plenum Press: London, UK, 1989; Volume 10.

11. Stanilov, K. Taking stock of post-socialist urban development: A recapitulation. In The Post-Socialist City: Urban Form and Space Transformations in Central and Eastern Europe after Socialism; Stanilov, K., Ed.; Springer Science \& Business Media: Dodrecht, The Netherlands, 2007; Volume 92.

12. Madanipour, A. Public spaces of European cities. Nord. Arkit. 2005, 1, 7-16.

13. Low, S.; Smith, N. (Eds.) The Politics of Public Space; Routledge: London, UK, 2013.

14. Magalhães, C.D.; Carmona, M. Innovations in the management of public space: Reshaping and refocusing governance. Plan. Theory Pract. 2006, 7, 289-303. [CrossRef]

15. Carmona, M.; De Magalhaes, C.; Hammond, L. Public Space: The Management Dimension; Routledge: London, UK, 2008.

16. Beck, H. Linking the quality of public spaces to quality of life. J. Place Manag. Dev. 2009, 2, $240-248$. [CrossRef]

17. Doratli, N. Revitalizing historic urban quarters: A model for determining the most relevant strategic approach. Eur. Plan. Stud. 2005, 13, 749-772. [CrossRef]

18. Soule, J. Urbanization and cultural conservation-A summary of policies and tools in the United States. In Managing Historic Cities World Heritage Papers; UNESCO: Paris, France, 2010; Volume 27, pp. 73-81.

19. Szirmai, V. Socially sustainable urban development in the historic urban centres of East Central Europe. Discuss. Pap. 2006, 20-38.

20. Carmona, M. Contemporary public space, part two: Classification. J. Urban Des. 2010, 15, 157-173. [CrossRef]

21. Kochanowska, D. Przestrzeń publiczna-Kluczowy element miasta współczesnego-Zintegrowana czy podzielona. In Problemy Kształtowania Przestrzeni Publicznych; Lorens, P., Martyniuk-Pęczek, J., Eds.; Wydawnictwo Urbanista: Gdańsk, Poland, 2010.

22. Bravo, D. The Flaneurs surprise, lessons from the European prize for urban public space 2000-2010. In Favour of Public Space. Ten Years of the European Prize for Urban Public Space; Centre de Cultura Contemporania de Barcelona and ACTAR: Barcelona, Spain, 2010; pp. 44-47.

23. Carmona, M. Contemporary public space: Critique and classification, part one: Critique. J. Urban Des. 2010, 15, 123-148. [CrossRef]

24. Nissen, S. Urban transformation from public and private space to spaces of hybrid character. Czech Sociol. Rev. 2008, 6, 1129-1149. [CrossRef]

25. Lorens, P. Theming urban spaces in post-socialist cities. In Proceedings of the 47th ISOCARP Congress, Wuhan, China, 24-28 October 2011. ISOCARP Paper Platform. 
26. Lam, K.C.; Ng, S.L.; Hui, W.C.; Chan, P.K. Environmental quality of urban parks and open spaces in Hong Kong. Environ. Monit. Assess. 2005, 111, 55-73. [CrossRef] [PubMed]

27. Ter, Ü. Quality criteria of urban parks: The case of Alaaddın Hill (Konya-Turkey). Afr. J. Agric. Res. 2011, 6, 5367-5376.

28. Chang, H.S.; Liao, C.H. Exploring an integrated method for measuring the relative spatial equity in public facilities in the context of urban parks. Cities 2011, 28, 361-371. [CrossRef]

29. Arnberberg, A. Urban densification and recreational quality of public urban green spaces-A Viennese case study. Sustainability 2012, 4, 703-720. [CrossRef]

30. Brambilla, G.; Gallo, V.; Zambon, G. The soundscape quality in some urban parks in Milan, Italy. Int. J. Environ. Res. Public Health 2013, 10, 2348-2369. [CrossRef] [PubMed]

31. Franco, S.F.; Macdonald, J.L. Measurement and valuation of urban greenness: Remote sensing and hedonic applications to Lisbon, Portugal. Reg. Sci. Urban Econ. 2018, 72, 156-180. [CrossRef]

32. Senetra, A.; Krzywnicka, I.; Mielke, M. An analysis of the spatial distribution, influence and quality of urban green space-A case study of the Polish city of Tczew. Bull. Geogr. Socio Econ. Ser. 2018, 42, 129-149. [CrossRef]

33. van Melik, R.G. Changing public space. The recent redevelopment of Dutch city squares. In Netherlands Geographical Studies; Utrecht University: Utrecht, The Netherlands, 2008; p. 373.

34. Mehta, V. The street: A quintessential social public space. Routledge: The role of public space. J. Environ. Psychol. 2013, 32, 401-409.

35. Oranratmanee, R.; Sachakul. Streets as public spaces in Southeast Asia: Case studies of Thai pedestrian streets. J. Urban Des. 2014, 19, 211-229. [CrossRef]

36. Carr, S.; Stephen, C.; Francis, M.; Rivlin, L.G.; Stone, A.M. Public Space; Cambridge University Press: Cambridge, UK, 1992.

37. Taylor, B.T.; Fernando, P.; Bauman, A.E.; Williamson, A.; Craig, J.C.; Redman, S. Measuring the quality of public open space using Google Earth. Am. J. Prev. Med. 2011, 40, 105-112. [CrossRef] [PubMed]

38. Timperio, A.; Ball, K.; Salmon, J.; Roberts, R.; Crawford, D. Is availability of public open space equitable across areas? Health Place 2007, 13, 335-340. [CrossRef]

39. Yang, P.P.J.; Putra, S.Y.; Li, W. Viewsphere: A GIS-based 3D visibility analysis for urban design evaluation. Environ. Plan. B Plan. Des. 2007, 34, 971-992. [CrossRef]

40. Mavoa, S.; Koohsari, M.J.; Badland, H.M.; Davern, M.; Feng, X.; Astell-Burt, T.; Giles-Corti, B. Area-Level disparities of public open space: A geographic information systems analysis in metropolitan Melbourne. Urban Policy Res. 2015, 33, 306-323. [CrossRef]

41. Siregar, J.P. Assessment of public space quality using good public space index (case study of Merjosari Sub District, Municipality of Malang, Indonesia). Procedia Soc. Behav. Sci. 2014, 135, 10-17. [CrossRef]

42. Hurtubia, R.; Guevara, A.; Donoso, P. Using images to measure qualitative attributes of public spaces through SP surveys. Transp. Res. Procedia 2015, 11, 460-474. [CrossRef]

43. Abbasi, A.; Alalouch Ch Bramley, G. Open space quality in deprived urban areas: User perspective and use pattern. Procedia Soc. Behav. Sci. 2016, 216, 194-205. [CrossRef]

44. Szczepańska, A.; Pietrzyk, K. An evaluation of public spaces in historical centers of small towns-Case study. J. Urban Plan. Dev. 2019, 146, 1-12. [CrossRef]

45. Kothencz, G.; Blaschke, T. Urban parks: Visitors' perceptions versus spatial indicators. Land Use Policy 2017, 64, 233-244. [CrossRef]

46. Dębniewska, M.; Wojtowicz, K. Finansowanie działalności turystycznej na obszarach przyrodniczo cennych w regionie Warmii i Mazur. Ekon. Śr 2016, 1, 129-142.

47. Environmental Impact Assessment of the Strategy for the Socioeconomic Development of the Region of Warmia and Mazury until 2025; Funderko Korbel, Krok-Baściuk Sp. J.: Warsaw, Poland, 2013.

48. Strategy for the Socioeconomic Development of the Region of Warmia and Mazury until 2025; Executive Board of the Region of Warmia and Mazury: Olsztyn, Poland, 2013.

49. Morag Town Council. Abridged Historical and Urban Development Study, Conservation Guidelines for Morag; Morag Town Council: Morag, Poland, 1993.

50. Romasiuk, I.; Fikus-Wójcik, A.; Jaskulska, M.; Piszczek, A.; Rodzewicz, A.; Rościszewska, M.; Turzyński, M.; Podolska, W. A Study of Municipal Public Spaces-Workshop 2014. An Evaluation of the Attractiveness of Public Spaces; Biuro Rozwoju Gdańska: Gdańska, Poland, 2014. 
51. Natland, J. Urban by Design: An Evaluation of Public Spaces in Downtown New Westminster. Ph.D. Thesis, Simon Fraser University, Burnaby, BC, Canada, 2007.

52. Dymitrow, M. The effigy of urbanity or a rural parody? A visual approach to small-town public space. J. Cult. Geogr. 2014, 31, 1-31. [CrossRef]

53. Cafuta, M. Open space evaluation methodology and three dimensional evaluation model as a base for sustainable development tracking. Sustainability 2015, 7, 13690-13712. [CrossRef]

54. Karacor, E.; Akcam, E. Comparative analysis of the quality perception in public spaces of Duzce City. Curr. Urban Stud. 2016, 4, 257-266. [CrossRef]

55. Wojnarowska, A. Model for assessment of public space quality in town centers. Eur. Spat. Res. Policy 2016, 23, 81-109. [CrossRef]

56. Szczepańska, A.; Pietrzyk, K. A multidimensional analysis of spatial order in public spaces: A case study of the town Morag, Poland. Bull. Geogr. Socio Econ. Ser. 2019, 44, 115-129. [CrossRef]

57. United Nations. A/RES/70/1, Transforming Our World: The 2030 Agenda for Sustainable Development; ONZ, General Assembly, Resolution Adopted by the General Assembly on 25 September 2015; United Nations: New York, NY, USA, 2015.

58. United Nations. New urban agenda, United Nations. In Proceedings of the United Nations Conference on Housing and Sustainable Urban Development, Habitat III, Quito, Ecuador, 17-20 October 2016.

59. Urban agenda for the EU, pact of Amsterdam. In Proceedings of the Informal Meeting of EU Ministers Responsible for Urban Matters on 30 May 2016 in Amsterdam, Amsterdam, The Netherlands, 30 May 2016.

Publisher's Note: MDPI stays neutral with regard to jurisdictional claims in published maps and institutional affiliations.

(C) 2020 by the authors. Licensee MDPI, Basel, Switzerland. This article is an open access article distributed under the terms and conditions of the Creative Commons Attribution (CC BY) license (http://creativecommons.org/licenses/by/4.0/). 